\title{
Denosumab Treatment for Aggressive Multiple Recurrent Familial Central Giant-cell Granulomas
}

\author{
Eelis Rytkönen, Vuokko Ottavainen, Aleksi Rytkönen¹, Sanna Uusitalo, Petri Lehenkari ${ }^{2,3}$, George K. Sándor ${ }^{4}$ \\ Departments of Oral and Maxillofacial Surgery, and ${ }^{1}$ Pathology, Oulu University Hospital, ${ }^{2}$ Department of Anatomy, University of Oulu, ${ }^{3}$ Department of Orthopaedics, \\ Oulu University Hospital, ${ }^{4}$ Department of Oral and Maxillofacial Surgery, University of Oulu and Oulu University Hospital, Oulu, Finland
}

\section{Abstract}

Background: Aggressive familial giant-cell granulomas of the jaws can be severely deforming. Surgical and nonsurgical treatments may be associated with multiple recurrences. Denosumab, a new generation antiresorptive drug, is an osteoclast inhibitor, which may be particularly useful to manage such potentially disfiguring lesions. Materials and Methods: Two sisters, both with a history of multiple recurrent aggressive central giant-cell granuloma (CGCG)-like lesions in both jaws, were referred for management. All lesions were histologically consistent with the diagnosis of CGCG. The lesions were treated surgically with curettage and perilesional injection of triamcinolone. In particular, the older sister had four separate anatomic sites where some of her lesions had multiple recurrences necessitating three repeat procedures. A course of subcutaneous denosumab was administered following the last giant-cell granuloma removal in both sisters. Results: Bony healing was normal. No further recurrences were observed over 3.5 years of follow-up after denosumab therapy in either sister. Conclusions: In this small cohort comprising two sisters with multiple aggressive recurrent giant-cell granuloma lesions at multiple sites in the mouth, subcutaneous denosumab administration was associated with success over 3.5 years of follow-up. This report cautiously adds to the clinical experience in the use of denosumab for the treatment of recurrent aggressive familial CGCG lesions.

Keywords: Central giant-cell granuloma, denosumab, familial, mandible, maxilla

\section{INTRODUCTION}

Giant-cell tumors (GCTs) of bone are locally aggressive tumors found throughout the skeleton, in long bones, ${ }^{[1-3]}$ bones of the hand ${ }^{[4]}$ or feet, ${ }^{[5]}$ and in the spine. ${ }^{[6]}$ Central giant-cell granulomas (CGCGs) are locally aggressive oral cavity tumors with histology similar to other giant-cell lesions. ${ }^{[7,8]}$ CGCGs occur in the bones of the jaws while peripheral giant-cell granulomas occur in oral soft tissues. ${ }^{[9]}$ CGCGs have been classified based on the clinical and radiographic findings. ${ }^{[10,11]}$ Their classification includes aggressive and nonaggressive or quiescent variants, which may also include a familial variety. ${ }^{[12]}$ Aggressive familial CGCGs (AFCGCGs) of the jaws can be severely deforming and present with multiple recurrences. While these variants have been described, till date, there has been no molecular method of distinguishing the variants. ${ }^{[11]}$

The recurrence rate of CGCGs managed with different lines of treatment is reported as ranging from $11 \%$ to $72 \% \cdot{ }^{[7]}$ Surgical curettage or in aggressive lesions, resection are the most common therapies. ${ }^{[7,13]}$ However, even when using surgical

\begin{tabular}{|l|l|}
\hline \multicolumn{2}{|c|}{ Access this article online } \\
\hline Quick Response Code: & Website: \\
\hline & www.amsjournal.com \\
& \\
\hline
\end{tabular}

curettage, undesirable damage to the jaws, nerves, or teeth and developing tooth buds may often prove to be unavoidable. Destructive recurrences are frequent. ${ }^{[7,8]}$ Therefore, alternative therapies such as intralesional injection of corticosteroids have been suggested..$^{[7,11,14]}$ Subcutaneous administration of calcitonin $^{[15]}$ or antiangiogenic therapy with interferon alpha was described in several case reports with variable success. ${ }^{[16]}$ Unfortunately, randomized clinical trials regarding treatment outcomes of CGCGs are nonexistent. ${ }^{[13,17]}$ This retrospective review aims to describe two cases of AFCGCGs in siblings to add to the clinical experience of the use of denosumab, an antiresorptive medication which acts as an osteoclast inhibitor in the treatment of such rare lesions.

Address for correspondence: Prof. George K. Sándor, Discipline of Oral and Maxillofacial Surgery, Unit of Oral Health Sciences, University of Oulu, Dentopolis H-2130, Aapistie 3, FIN 90014, Oulu, Finland. E-mail: george.sandor@oulu.fi

This is an open access journal, and articles are distributed under the terms of the Creative Commons Attribution-NonCommercial-ShareAlike 4.0 License, which allows others to remix, tweak, and build upon the work non-commercially, as long as appropriate credit is given and the new creations are licensed under the identical terms.

For reprints contact: reprints@medknow.com

How to cite this article: Rytkönen E, Ottavainen V, Rytkönen A, Uusitalo S, Lehenkari P, Sándor GK. Denosumab treatment for aggressive multiple recurrent familial central giant-cell granulomas. Ann Maxillofac Surg 2018;XX:XX-XX. 


\section{Materials and Methods}

This study included two sisters both with a history of large, multiple, recurrent lytic lesions of the mandible and maxilla who were referred for the management of their giant-cell granulomas. The study was granted ethical approval as a retrospective study by the ethical committee of the Oulu University Hospital, and the data were treated according to the principles of the Helsinki Declaration.

\section{Case 1}

The older sister was 27 years of age at her initial presentation. Her first lesion was located in the left mandible at sites 33 and 34. The lesion was removed by extraction of tooth numbers 33 and 34 and by curettage. The lesion was found to be histologically consistent with a CGCG [Figure 1].

Healing was complicated by a recurrence of the mandibular lesion 1 year later involving sites 34-42 and a new separate mandibular lesion at site 38 . Both of these lesions were treated with curettage and the removal of teeth $32,31,41$, and 42. In addition, tooth 38 was removed during the same operating session together with curettage of a new posterior

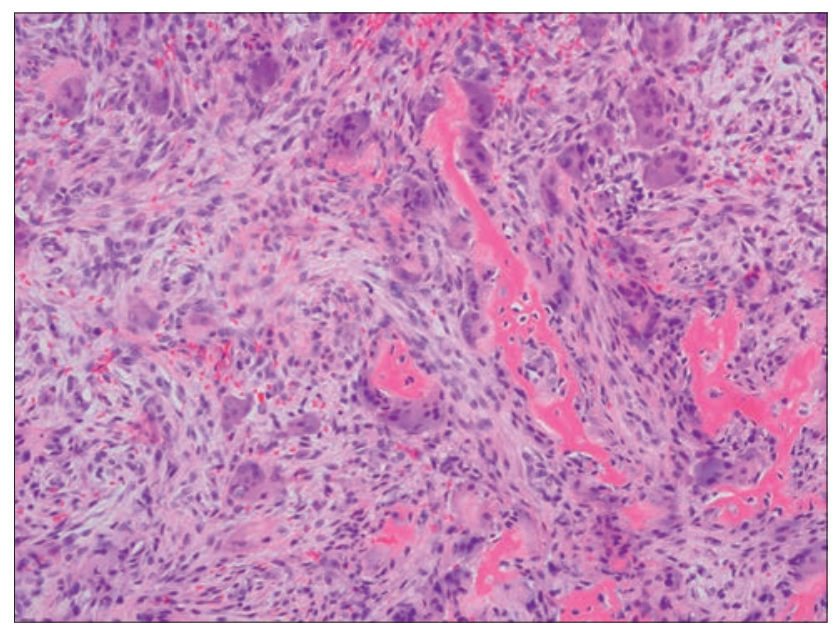

Figure 1: $\mathrm{H}$ and $\mathrm{E}$, stained photomicrograph from initial lytic mandibular lesion of sister 1 showing typical histological features of a central giant-cell granuloma with numerous giant cells and a fibrovascular stroma

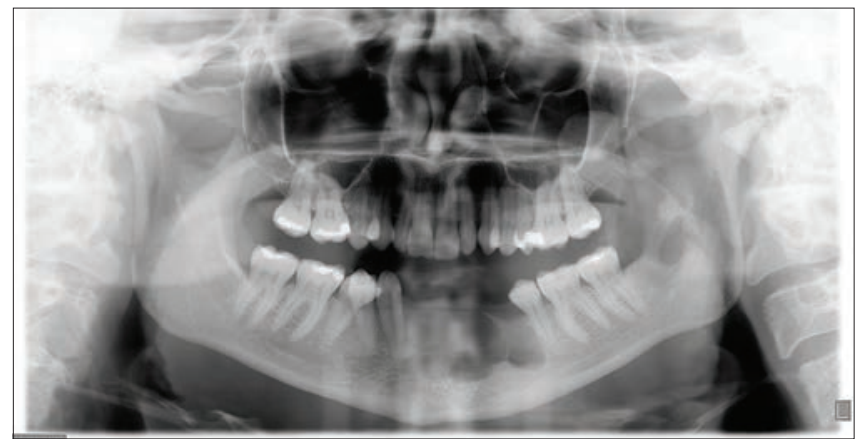

Figure 3: Orthopantomogram showing lesions in the parasymphyseal region of mandible, a second separate lesion at the left mandibular third molar and left posterior maxillary lesion in the third molar area extending into the maxillary sinus in sister 1 lesion [Figures 2 and 3]. The perilesional tissues were infiltrated with $20 \mathrm{mg}$ triamcinolone acetate (Lederspan, Lederle Laboratories, London, United Kingdom). Six months later, further new lytic lesions were found in the maxilla at sites 13 and 14 and sites 27 and 28 [Figure 3]. These were removed by curettage, and the perilesional tissues were also injected with $20 \mathrm{mg}$ of triamcinolone acetate. The histology of the tissues at all recurrent and new sites was consistent with CGCG.

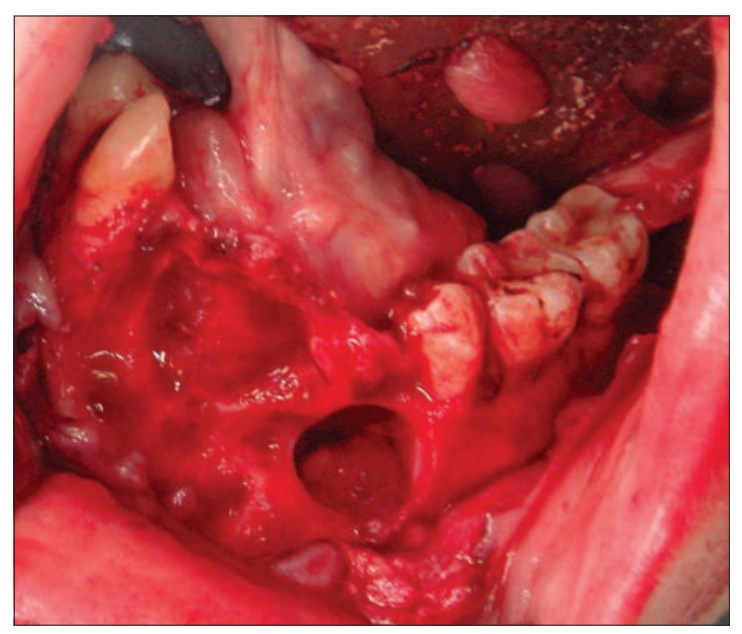

Figure 2: Intraoperative view of large lytic lesion of the parasymphyseal region of mandible and second lesion in the left posterior mandible of sister 1

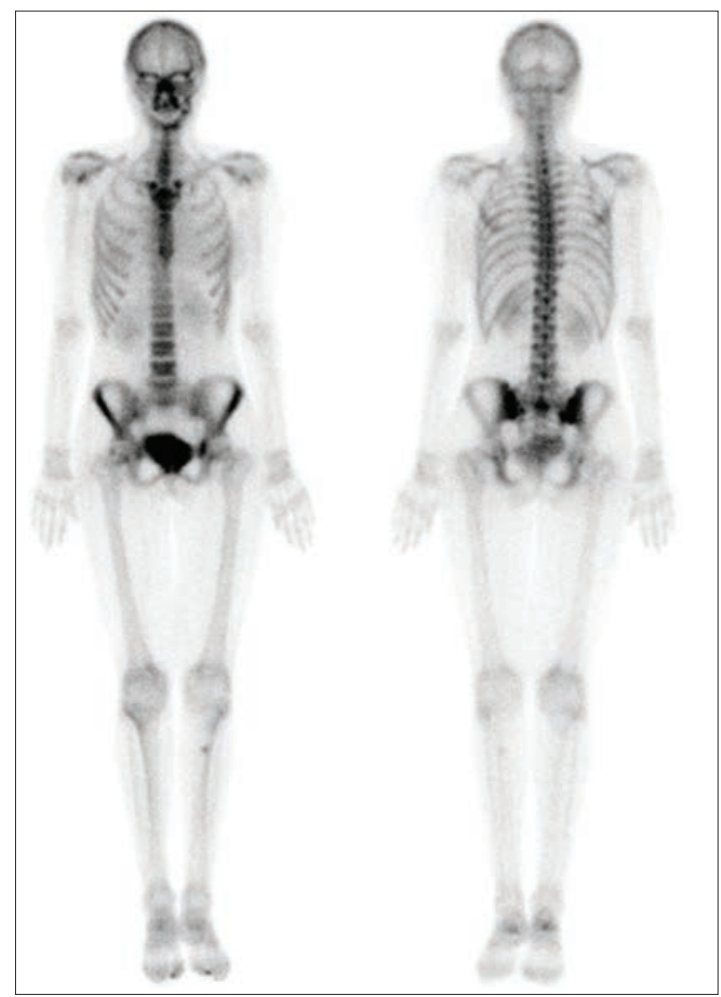

Figure 4: Bone scan in sister 1 showing increased uptake corresponding to lesions in the mandibular parasymphyseal area, left posterior mandible and left posterior maxilla 


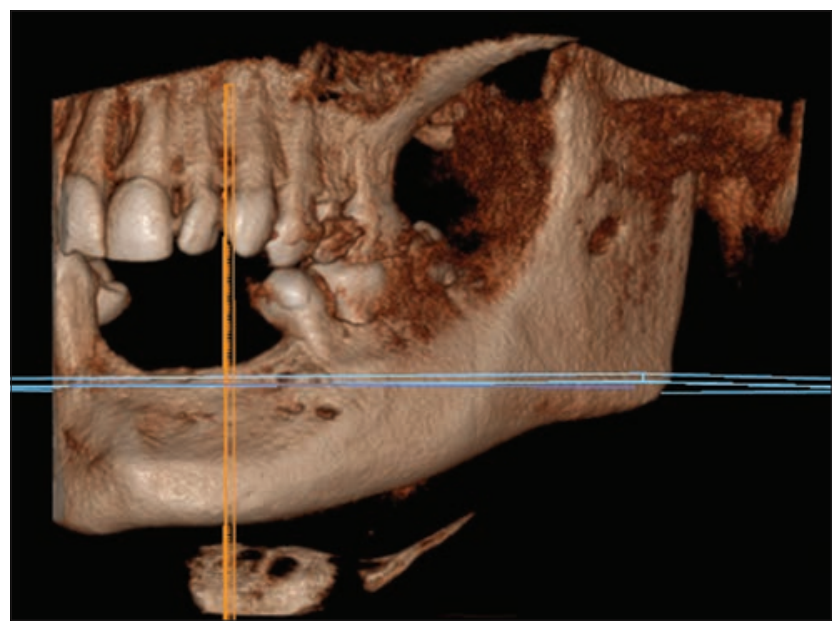

Figure 5: Cone beam computed tomography scan of sister 1 showing a three-dimensional reconstruction of the facial bones with healed parasymphyseal lesion

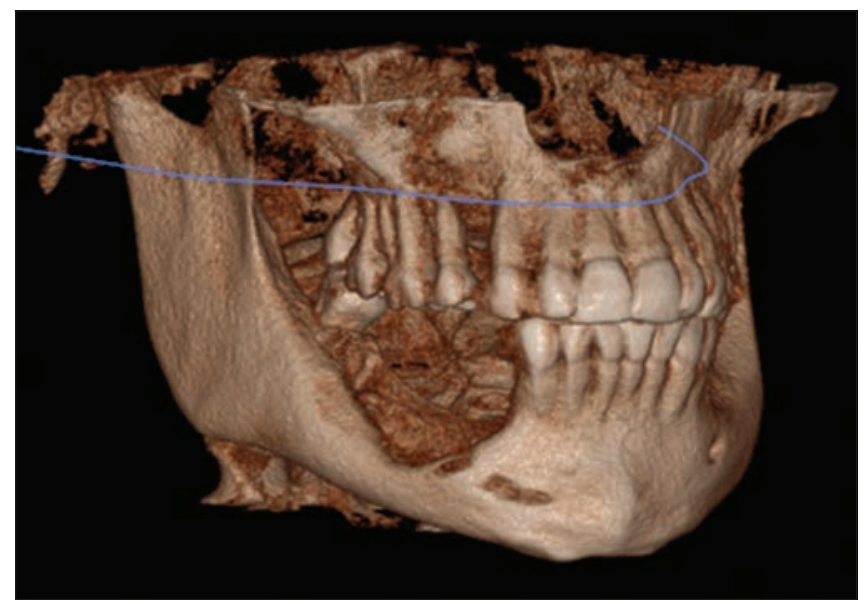

Figure 7: Cone beam computed tomography scan of sister 2 showing a three-dimensional reconstruction of the facial bones with lytic lesions of the right maxilla and right mandible

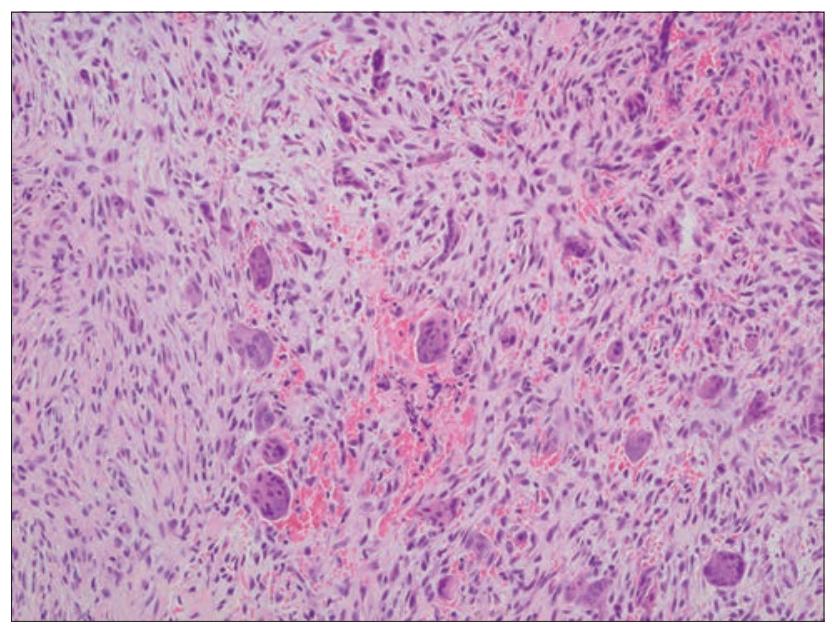

Figure 9: $\mathrm{H}$ and $\mathrm{E}$, stained photomicrograph from initial mandibular lesion of sister 2 showing numerous giant cells and a fibrovascular stroma, features typical of a central giant-cell granuloma

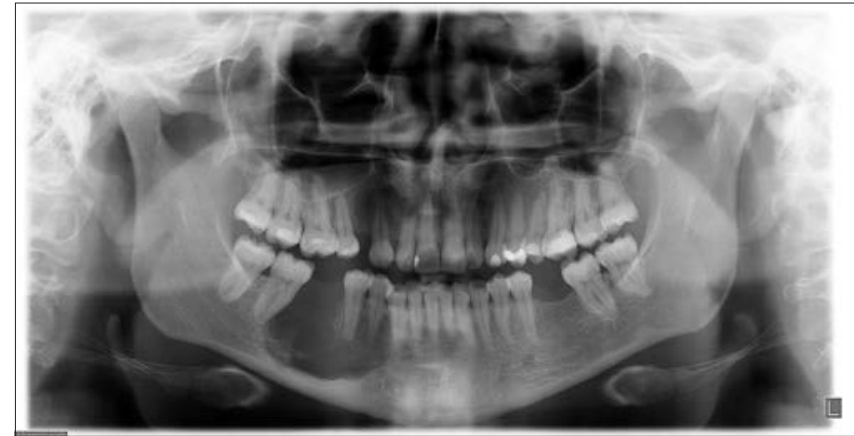

Figure 6: Orthopantomogram showing separate lytic lesions in the right maxilla at the canine tooth and in the right posterior mandible in sister 2

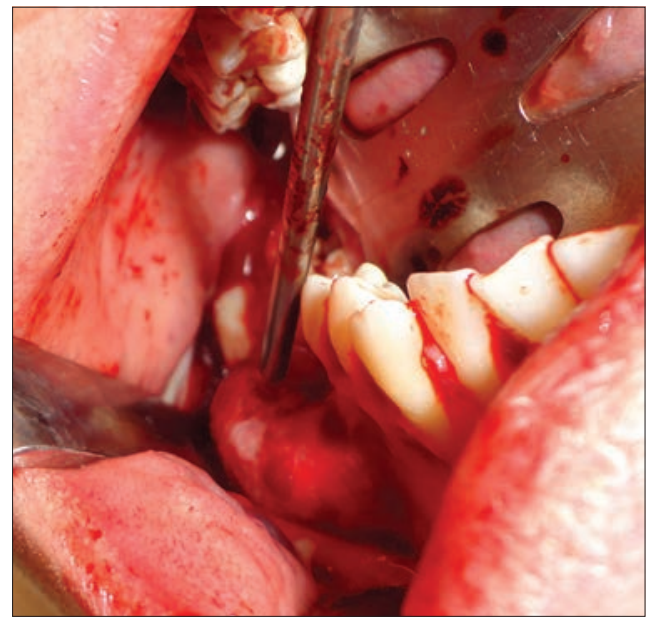

Figure 8: Intraoperative view of large central giant-cell granuloma lesion of the left mandibular body in sister 2

Serum total and ionized calcium, phosphorus, parathyroid hormone (PTH), and alkaline phosphatase levels were all within normal limits. An ultrasound of the neck did not reveal any evidence of adenoma of the parathyroid glands. This sister was in her second trimester of pregnancy, so further radiographic tests were delayed. After uneventful delivery of her baby, the patient underwent cone beam computed tomography (CBCT) examination [Figure 4] and bone and positron emission tomography (PET) scans with no additional skeletal lesions being identified [Figure 5]. The decision was made to treat the patient with a single subcutaneous dose of $120 \mathrm{mg}$ denosumab (XGEVA, Amgen, Thousand Oaks, California, USA). There was a recurrent lesion at tooth 14 which was extracted, and the area was infiltrated with triamcinolone $20 \mathrm{mg}$. The patient received a further course of three injections of $120 \mathrm{mg}$ denosumab subcutaneously over 3 months. No further recurrences were noted over the next 3.5 years of active follow-up.

\section{Case 2}

The second sister was 29 years of age at the first presentation. She was noted to have two separate lytic lesions one in the maxilla at site 13 and another larger lesion in the mandible occupying sites 44, 45, 46, and 47 [Figures 6 and 7]. 
A biopsy [Figure 8] was consistent with CGCG [Figure 9]. The two lesions were removed, and the perilesional tissues were injected with triamcinolone acetate $20 \mathrm{mg}$. Serum PTH, serum total and ionized calcium, phosphorus, alkaline phosphatase levels, and a PET scan were all within normal limits. Taking the aggressive history of her sister's tumors into account, the second sister was also offered denosumab treatment. She received a course of three injections of $120 \mathrm{mg}$ denosumab subcutaneously over 3 months. No recurrences or new CGCG lesions were noted, since the denosumab administration, over the next 4 years of active follow-up.

\section{RESULTS}

All lesions in both sisters were histologically consistent with the diagnosis of CGCGs. The lesions were treated surgically, with curettage and perilesional injection of triamcinolone. In particular, the older sister had four separate sites, in two jaws, where her lesions had multiple recurrences necessitating three repeat procedures. Denosumab treatment was administered as a first-time adjuvant dose 8 months following the last AFCGCG resection and the safe delivery of her baby. All surgical sites healed uneventfully without further recurrences.

\section{Genetics}

A genetics consultation was arranged. DNA analysis of both sisters was undertaken to rule out Cherubism and Noonan syndrome with scrutiny for the SH3BP2 gene and to rule out nonsense mutations of R234X exon 7 of the HRPT2 gene. Chromosomal mapping was performed to rule out any translocations.

\section{Discussion}

The recurrence rate of CGCGs managed with curettage, resection, intralesional steroid therapy, and calcitonin or antiangiogenic therapy is unacceptably high. ${ }^{[7]}$ Denosumab is a new generation antiresorptive medication. It is an osteoclast inhibitor which radically differs from bisphosphonate medications. Some clinical trials in the orthopedic literature have shown that denosumab is a novel and effective therapeutic option for aggressive and recurrent GCTs in the spine and femur. ${ }^{[6,18,19]}$ In GCTs, 13 consistently upregulated proteins and 19 consistently downregulated proteins have been identified in pre- and postdenosumab administration samples that were involved in the receptor activator of nuclear factor kappa B/RANK ligand (RANK/RANKL) pathway in patients with tumors located in the femur. ${ }^{[18]}$ This suggests that these identified proteins may play a critical functional role in the osteolytic process of GCTs.

Denosumab has also been suggested to be useful in the management of potentially disfiguring recurrent CGCGs of the jaws. ${ }^{[20-23]}$ The authors of this current publication have used denosumab to treat the two sisters in this report with AFCGCGs. Denosumab is described as a fully human monoclonal antibody against the RANKL. ${ }^{[6]}$ Since giant-cell granulomas are rich in osteoclast-like cells, it seems logical that denosumab has potential in the management of such lesions. At the time of the writing of this manuscript, denosumab had been used in a total of 11 cases reported in the English literature thus far. ${ }^{[20-23]}$

Antiresorptive therapy is associated with the risk of osteonecrosis of the jaws (ONJs). ${ }^{[24]}$ The frequency of ONJ in oncology patients receiving oncologic doses of bisphosphonate or denosumab is estimated at $1 \%-15 \%$. The frequency in the osteoporosis patient population receiving much lower doses of bisphosphonate or denosumab is estimated at $0.001 \%-0.01 \% .{ }^{[25]}$ Nonetheless, a case of delayed wound healing resembling ONJ has been reported in one patient receiving denosumab treatment for an aggressive CGCG from a series of five cases. ${ }^{[20]}$ Other adverse effects include nail changes and pain in the CGCG lesions during denosumab therapy. The pain is thought to be due to the active mineralization process with possible pressure on sensory nerves. ${ }^{[23]}$

The reported dosage and duration of denosumab therapy vary in the literature. ${ }^{[20-23]}$ The effectiveness and response have been followed on the basis of patient symptoms and radiological parameters. The doses range from a single $120 \mathrm{mg}$ dose to a series of three doses of $120 \mathrm{mg}$ of subcutaneous denosumab to a longer course which is determined by the individual patient's response to denosumab treatment following PET, $\mathrm{CT}$, or magnetic resonance imaging scans. ${ }^{[23]}$

Denosumab has been used as adjuvant therapy in CGCGs where surgery has failed or was not possible. ${ }^{[20-23]}$ In the case of GCTs of the femur, when denosumab is given before surgery, the bone which subsequently replaced the GCT was found to be very dense and difficult to manage. Based on this observation in the femur with GCTs, it may be prudent to recommend that in the case of CGCGs of the jaws that denosumab be used as a postsurgical adjuvant therapy rather than preoperatively.

While there is a familial aspect in the history of aggressive CGCGs in these two sisters, neither sister possessed the gene for Cherubism or Noonan syndrome. ${ }^{[26,27]}$ No chromosomal translocations were found.

\section{Conclusions}

While subcutaneous denosumab may represent a promising new treatment in the potential management of aggressive CGCGs of the jaws, further clinical trials are necessary with this rare tumor. Until the results of such clinical trials are available, the authors recommend a cautious approach with the application of denosumab treatment in aggressive cases of CGCGs of the jaws.

\section{Declaration of patient consent}

The authors certify that they have obtained all appropriate patient consent forms. In the form the patient(s) has/have given his/her/their consent for his/her/their images and other clinical information to be reported in the journal. The patients 
understand that their names and initials will not be published and due efforts will be made to conceal their identity, but anonymity cannot be guaranteed.

\section{Financial support and sponsorship}

Oulu University Hospital VTR Grants, Oulu, Finland.

\section{Conflicts of interest}

There are no conflicts of interest.

\section{References}

1. Jaffe HL. Giant-cell reparative granuloma, traumatic bone cyst, and fibrous (fibro-oseous) dysplasia of the jawbones. Oral Surg Oral Med Oral Pathol 1953;6:159-75.

2. Amanatullah DF, Clark TR, Lopez MJ, Borys D, Tamurian RM. Giant cell tumor of bone. Orthopedics 2014;37:112-20.

3. López-Pousa A, Martín Broto J, Garrido T, Vázquez J. Giant cell tumour of bone: New treatments in development. Clin Transl Oncol 2015;17:419-30.

4. Perkins A, Izadpanah A, Sinno H, Bernard C, Williams H. Giant cell reparative granuloma of the proximal phalanx: A case report and literature review. Can J Plast Surg 2011;19:e19-21.

5. Kamoun K, Sellami T, Jlailia Z, Abid L, Jenzri M, Bouaziz M, et al. Giant cell reparative granuloma of the hallux following enchondroma. Pan Afr Med J 2015;22:363.

6. Akeda K, Kasai Y, Sakakibara T, Matsumine A, Takegami N, Yamada J, et al. Effect of denosumab on recurrent giant cell reparative granuloma of the lumbar spine. Spine (Phila Pa 1976) 2015;40:E601-8.

7. de Lange J, van den Akker HP, van den Berg H. Central giant cell granuloma of the jaw: A review of the literature with emphasis on therapy options. Oral Surg Oral Med Oral Pathol Oral Radiol Endod 2007;104:603-15.

8. Pogrel AM. The diagnosis and management of giant cell lesions of the jaws. Ann Maxillofac Surg 2012;2:102-6.

9. Cloutier M, Charles M, Carmichael RP, Sándor GK. An analysis of peripheral giant cell granuloma associated with dental implant treatment. Oral Surg Oral Med Oral Pathol Oral Radiol Endod 2007;103:618-22.

10. Chuong R, Kaban LB, Kozakewich H, Perez-Atayde A. Central giant cell lesions of the jaws: A clinicopathologic study. J Oral Maxillofac Surg 1986;44:708-13.

11. El Hadidi YN, Ghanem AA, Helmy I. Injection of steroids intralesional in central giant cell granuloma cases (giant cell tumor): Is it free of systemic complications or not? A case report. Int J Surg Case Rep 2015;8C: 166-70.

12. Lewis KK, Herold J. Familial giant cell lesions of the mandible - Unusual occurrence. J Oral Maxillofac Surg 2013;71:e75-6.
13. deLange J, van den Akker HP, Klip H. Incidence and disease free survival after surgical therapy of central giant-cell granulomas of the jaw in The Netherlands: 1990-1995. Head and Neck 2004;26:792-5.

14. Kermer C, Millesi W, Watzke IM. Local injection of corticosteroids for central giant cell granuloma. A case report. Int J Oral Maxillofac Surg 1994;23:366-8.

15. Harris M. Central giant cell granulomas of the jaws regress with calcitonin therapy. Br J Oral Maxillofac Surg 1993;31:89-94.

16. Kaban LB, Troulis MJ, Ebb D, August M, Hornicek FJ, Dodson TB, et al. Antiangiogenic therapy with interferon alpha for giant cell lesions of the jaws. J Oral Maxillofac Surg 2002;60:1103-11.

17. Suárez-Roa Mde L, Reveiz L, Ruíz-Godoy Rivera LM, Asbun-Bojalil J, Dávila-Serapio JE, Menjívar-Rubio AH, et al. Interventions for central giant cell granuloma (CGCG) of the jaws. Cochrane Database Syst Rev 2009;(4):CD007404. doi: 10.1002/14651858.CD007404.pub2.

18. Mukaihara K, Suehara Y, Kohsaka S, Akaike K, Tanabe Y, Kubota D, et al. Protein expression profiling of giant cell tumors of bone treated with denosumab. PLoS One 2016;11:e0148401.

19. Thomas D, Henshaw R, Skubitz K, Chawla S, Staddon A, Blay JY, et al. Denosumab in patients with giant-cell tumour of bone: An open-label, phase 2 study. Lancet Oncol 2010;11:275-80.

20. Schreuder WH, Coumou AW, Kessler PA, de Lange J. Alternative pharmacologic therapy for aggressive central giant cell granuloma: Denosumab. J Oral Maxillofac Surg 2014;72:1301-9.

21. Naidu A, Malmquist MP, Denham CA, Schow SR. Management of central giant cell granuloma with subcutaneous denosumab therapy. J Oral Maxillofac Surg 2014;72:2469-84.

22. Bredell M, Rordorf T, Kroiss S, Rücker M, Zweifel DF, Rostetter C. Denosumab as a Treatment Alternative for Central Giant Cell Granuloma: A Long-Term Retrospective Cohort Study. J Oral Maxillofac Surg 2018;76:775-784.

23. Gupta B, Stanton N, Coleman H, White C, Singh J. A novel approach to the management of a central giant cell granuloma with denosumab: A case report and review of current treatments. J Craniomaxillofac Surg 2015;43:1127-32.

24. Lam DK, Sándor GK, Holmes HI, Evans AW, Clokie CM. A review of bisphosphonate-associated osteonecrosis of the jaws and its management. J Can Dent Assoc 2007;73:417-22.

25. Khan AA, Morrison A, Kendler DL, Rizzoli R, Hanley DA, Felsenberg D, et al. Case-based review of osteonecrosis of the jaw (ONJ) and application of the international recommendations for management from the international task force on ONJ. J Clin Densitom 2017;20:8-24.

26. Mangion J, Rahman N, Edkins S, Barfoot R, Nguyen T, Sigurdsson A, et al. The gene for cherubism maps to chromosome 4p16.3. Am J Hum Genet 1999;65:151-7.

27. Ueki Y, Tiziani V, Santanna C, Fukai N, Maulik C, Garfinkle J, et al. Mutations in the gene encoding c-Abl-binding protein SH3BP2 cause cherubism. Nat Genet 2001;28:125-6. 